\title{
The Use of a Uniform Technique for Harmonization and Generalization in Assessing the Flood Discharge Frequencies of Long Return Period Floods in the Danube River Basin
}

\author{
Veronika Bačová Mitková *D, Pavla Pekárová (D), Dana Halmová ${ }^{1}$ and Pavol Miklánek (D) \\ Institute of Hydrology, Slovak Academy of Sciences, Dúbravská cesta 9, 84104 Bratislava, Slovakia; \\ pekarova@uh.savba.sk (P.P.); halmova@uh.savba.sk (D.H.); miklanek@uh.savba.sk (P.M.) \\ * Correspondence: mitkova@uh.savba.sk; Tel.: +42-12-3229-3502
}

check for

updates

Citation: Bačová Mitková, V.;

Pekárová, P.; Halmová, D.;

Miklánek, P. The Use of a Uniform

Technique for Harmonization and

Generalization in Assessing the Flood

Discharge Frequencies of Long

Return Period Floods in the Danube

River Basin. Water 2021, 13, 1337.

https://doi.org/10.3390/w13101337

Academic Editor: Leonardo V. Noto

Received: 24 March 2021

Accepted: 6 May 2021

Published: 11 May 2021

Publisher's Note: MDPI stays neutral with regard to jurisdictional claims in published maps and institutional affiliations.

Copyright: (C) 2021 by the authors Licensee MDPI, Basel, Switzerland. This article is an open access article distributed under the terms and conditions of the Creative Commons Attribution (CC BY) license (https:/ / creativecommons.org/licenses/by/ $4.0 /)$.

\begin{abstract}
The flow regime conditions of the Danube River are continually changing. These changes are the result of natural processes and anthropogenic activities. The territory of the Danube River Basin is one of the most flood-endangered regions in Europe and assessing the design discharges along the Danube channel is complicated by the different estimation methods that are applied in particular countries. For this reason, it is necessary to harmonize flood design value assessment methods. The long-term maximum annual discharge series of the Danube River and other rivers in the Danube basin were analyzed and used to estimate the flood design values. We used the Log-Pearson type III distribution, which is one of the most widely used theoretical probability distributions to estimate extremes. This distribution can be flexibly applied to extreme values depending on the skew coefficient. We also analyzed the effect of the inclusion and exclusion of the historical extremes in the processed dataset. The results show that the inclusion of historical floods and the regionalization of the Log-Pearson type III distribution skew parameter can change the design discharges.
\end{abstract}

Keywords: Danube river; log-Pearson type III distribution; design discharges; historic floods; regionalization

\section{Introduction}

Flood frequency analysis plays a major role in the design of hydraulic structures and flood control management. One of the fundamental problems of flood hydrology was (and still is) establishing the relationship between peak discharges of flood waves and the probability of their return period. Extrapolation from these variables (a so-called frequency curve) is especially necessary for water management and flood control plans. Directive 2007/60/EC of the European Parliament of 23 October 2007 concerning the assessment and management of flood risks requires member states to draw up flood hazard maps of floods with long return periods (from 100 to 1000 years). On the basis of the statistics, it is clear that the extrapolation of the data is very sensitive to both the length of the data series and the inclusion of historic extremes in the data series. Investigation of the history of extreme flood event frequency, severity and duration provides a greater understanding of the region's extreme event characteristics and the probability of occurrence at various levels of severity. This type of information is beneficial in the development of extreme response and mitigation strategies and preparedness plans. Many hydrologists consider mathematician E.J. Gumbel to be one of the pioneers in the development of extreme value theory [1]. In [2], the theory of extremes was applied to different areas, with a main focus on hydrology, the definition of floods and a practical method for estimating flood frequencies. The correct estimation of potential culminations of floods requires the inclusion of longterm observational data series and historic preinstrumental data to statistically analyze data series [3-10]. An extensive overview of scientific papers dealing with the historical floods and individual disastrous flood events in the past millennium for the rivers in various 
European countries can be found in [11]. Moreover, historic floods that occurred in the Danube River Basin are summarized in the book of Pekárová et al. [12].

Another important factor in the correct estimation of extremes is the uncertainty of the applied statistical method. For example, the estimation of uncertainty for design discharges was investigated in [13-16]. In [17], four models were compared in terms of goodness of fit, their uncertainties, parameter estimation methods and implications for estimating flood quantiles. Regional flood frequency analyses (RFFA) using L-moments and annual maximum series (AMS) methods for Pannonia basins were conducted in [18]. The following conditions are among the basic assumptions for the application of the frequency analyses of maximum annual discharge:

- Maximum annual discharges must be independent and stochastic;

- Processes influencing the runoff process are stationary with respect to time (homogeneity of the series);

- Statistical characteristics of the measured data series (series of maximum annual discharge) represent the past, presence, and future.

A second problem regarding hydrology is hydrological regionalization concerns the manner in which the transfer of data to the ungauged basins, or to deficient data sites, is carried out. There are two main procedures used for this transfer. The first consists of discovering certain relationships for the spatial interpolation of the principal statistics of the probability curves; the second tries to eliminate the shortcomings of the first. This consists of determining several statistical distribution curves of the standardized annual maximum discharge. Standardization is achieved by dividing the maximum annual discharges by their average magnitude. These standardized (or dimensionless) curves are often called growth curves [19]. All methods of estimating floods with a very long return period are associated with great uncertainties. Determining the specific values of a 500 or 1000-year flood for engineering purposes is extremely complex. Nowadays, hydrologists are required to determine both the specific design values of the extremes and to specify confidence intervals in which the discharge of a given, for example, 100, 500 or 1000-year flood may occur, with a probability of $90 \%$. Globally, there are a huge number of scientific papers that deal with the selection and testing of theoretical probability distributions for estimating the maximum values of hydrological characteristics. The application and selection of a particular probability distribution function, the method of parameter estimation and the analyzed period depend on the calculation method generally used in a given country [20-24]. For example, since 1967 in the United States, Log-Pearson type III (LPIII) distribution has often been chosen by experts as "The distribution of choice for floods" [25]. The LPIII is used to estimate extremes in many natural processes and is one of the most commonly used probability distributions in hydrology [26-29]. In [30], the use of the Log-Person distribution to estimate maximum annual precipitation and discharge was investigated. They concluded that this distribution is more suitable for discharges with higher return periods, whereas for annual floods, the existence of an upper bound for the distribution may cause uncertainty in some cases. The use of historical information to improve flood quantile estimates was investigated in [31]. The authors showed that much of the information contained in historical flood records is connected with knowing the number of exceedances of the threshold rather than the magnitudes of the "historic" floods. Various authors, e.g., see [32-34], prefer the generalized extreme value (GEV) distribution for estimating hydrological extremes. In [35], the authors examined the suitability of several types of probability distribution (GEV, LPIII and Gumbel) for estimating T-year discharges. The results of [35] showed that the GEV distribution was applicable to the Upper Thames River Watershed data, but they recommend further research. Excepting the aforementioned factors, the estimation of $T$-year discharges is finally influenced by the type of theoretical probability distribution function used. The choice of theoretical probability distribution function should accurately represent the uncertainty and variability of the hydrological problem. For large international basins, such as the Danube River Basin, 
it is necessary to synchronize the methodology and to prepare common procedures for determining flood hazards.

Therefore, the aim of the paper is to propose a uniform methodology for the harmonization and generalization of design value assessments of flood discharges in stations along the Danube River. We used LPIII distribution as a mathematical tool. The skew coefficient is a measure of the asymmetry of that distribution and is sensitive to extreme events. In the first part of this paper, we analyze the effect of the inclusion or exclusion of historical extremes in the processed dataset on design value estimation. The second part of the paper is focused on the estimation of the relationship between the skew coefficient of the Log-Pearson type III distribution function and runoff depth, basin area, and elevation, for the purpose of regionalization. The last section offers the results, conclusions and a short discussion.

\section{Materials and Methods}

\subsection{Materials}

The Danube River is the second greatest river in Europe, after the Volga. The basin covers an area of $817,000 \mathrm{~km}^{2}$ (Figure 1). The river originates in the Black Forest in Germany at the confluence of the Briga and the Breg streams. The Danube then discharges southeast for $2872 \mathrm{~km}(1785 \mathrm{mi})$, passing through four Central European capitals before emptying into the Black Sea via the Danube Delta in Romania and Ukraine. The Danube River Basin landscape geomorphology is characterized by a diversity of morphological patterns, and the river channel itself can be divided into six sections (Figure 1). The territory of the Danube River Basin is also one of the most flood-endangered regions in Europe. Therefore, it is vital to have complete data of the flood regime to be able to generalize such information on the basis of long-term observations from the whole Danube territory. The occurrence of large floods on the Danube River is described in detail in many publications [8,11,36-42].

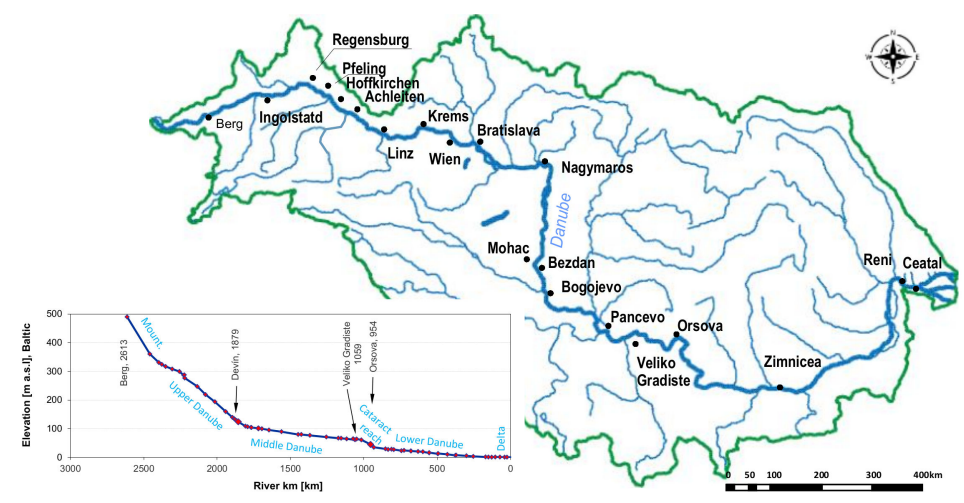

Figure 1. Diagram of the Danube River Basin, water gauging stations along the Danube River, and the six sections of the Danube Basin based on the landscape geomorphology.

In this study, the long-term data of annual maximum discharges from 20 stations (Table 1) along the Danube River from Germany to Ukraine were used to determine the $T$-year maximum discharges. The basic statistical characteristics of the stations are presented in Table 1. In Figure 2, examples of the maximum annual discharges in the upper (Hofkirchen gauge), central (Bratislava gauge), and lower Danube (Orsova/Turnu Severin gauge) from 142 to 193 years are shown. 
Table 1. List of the gauging stations along the Danube River. LAT: latitude; LONG: longitude; $\mathbf{Q}_{\mathrm{amax}}$ : long-term average of the maximum annual discharge.

\begin{tabular}{|c|c|c|c|c|c|c|c|c|}
\hline Gauge & River km & Period & Country & Area $\left[\mathrm{km}^{2}\right]$ & LAT & LONG & $\begin{array}{c}\text { Elevation } \\
\text { [m a.s.1] }\end{array}$ & $\underset{\left[\mathrm{m}^{3} \mathrm{~s}^{-1}\right]}{\mathrm{Q}_{\mathrm{amax}}}$ \\
\hline Berg & 2613 & 1930-2007 & GE & 4047 & 48.27 & 9.73 & 489.48 & 204 \\
\hline Ingolstadt & 2458.3 & 1940-2007 & GE & 20,001 & 48.75 & 11.42 & 359.97 & 1110 \\
\hline $\begin{array}{l}\text { Regensburg- } \\
\text { Schwabelweis }\end{array}$ & 2376.1 & 1924-2007 & GE & 35,399 & 49.02 & 12.14 & 324.06 & 1532 \\
\hline Pfelling & 2300 & 1926-2007 & GE & 37,757 & 48.88 & 12.75 & 307.73 & 1516 \\
\hline Hofkirchen & 2256.9 & $1826-2013$ & GE & 47,496 & 48.68 & 13.12 & 299.17 & 1896 \\
\hline Achleiten & 2150 & 1901-2007 & GE & 76,653 & 48.58 & 13.5 & 287.27 & 4146 \\
\hline Linz & 2135.2 & $1821-2013$ & AT & 79,490 & 48.31 & 14.3 & 247.06 & 3670 \\
\hline $\begin{array}{c}\text { Stein-Krems } \\
\text { (Kienstock) }\end{array}$ & 2002.7 & 1828-2006 & AT & 96,045 & 48.38 & 15.46 & 193.32 & 5372 \\
\hline Wien-Nussdorf & 1934.1 & 1828-2006 & AT & 101,731 & 48.25 & 16.3 & 157 & 5301 \\
\hline Devin/Bratislava & 1868.8 & 1876-2013 & SK & 131,338 & 48.14 & 17.1 & 132.86 & 5884 \\
\hline Nagymaros & 1694.6 & $1893-2007$ & $\mathrm{HU}$ & 183,534 & 47.78 & 18.95 & 99.37 & 5598 \\
\hline Mohács & 1446.8 & 1930-2007 & $\mathrm{HU}$ & 209,064 & 46 & 18.67 & 79.19 & 5063 \\
\hline Bezdan & 1425.5 & 1940-2006 & SR & 210,250 & 45.85 & 18.87 & 79.29 & 4974 \\
\hline Bogojevo & 1367.4 & 1940-2006 & SR & 251,593 & 45.53 & 19.08 & 76.11 & 5675 \\
\hline Pancevo & 1153.3 & 1940-2006 & SR & 525,009 & 44.87 & 20.46 & 65.98 & 10,147 \\
\hline Veliko Gradiste & 1060 & 1931-2007 & SR & 570,375 & 44.8 & 21.4 & 60.83 & 10,529 \\
\hline $\begin{array}{l}\text { Orsova-Turnu } \\
\text { Severin }\end{array}$ & 955 & 1840-2006 & $\mathrm{RO}$ & 576,232 & 44.7 & 22.42 & 44.76 & 10,295 \\
\hline Zimnicea & 554 & 1931-2010 & $\mathrm{RO}$ & 658,400 & 43.63 & 25.36 & 16.06 & 11,087 \\
\hline Reni & 132 & 1921-2010 & UKR & 805,700 & 45.45 & 28.27 & 4 & 11,217 \\
\hline Ceatal Izmail & 72 & 1931-2010 & $\mathrm{RO}$ & 807,000 & 45.22 & 28.73 & 0.2 & 11,173 \\
\hline
\end{tabular}
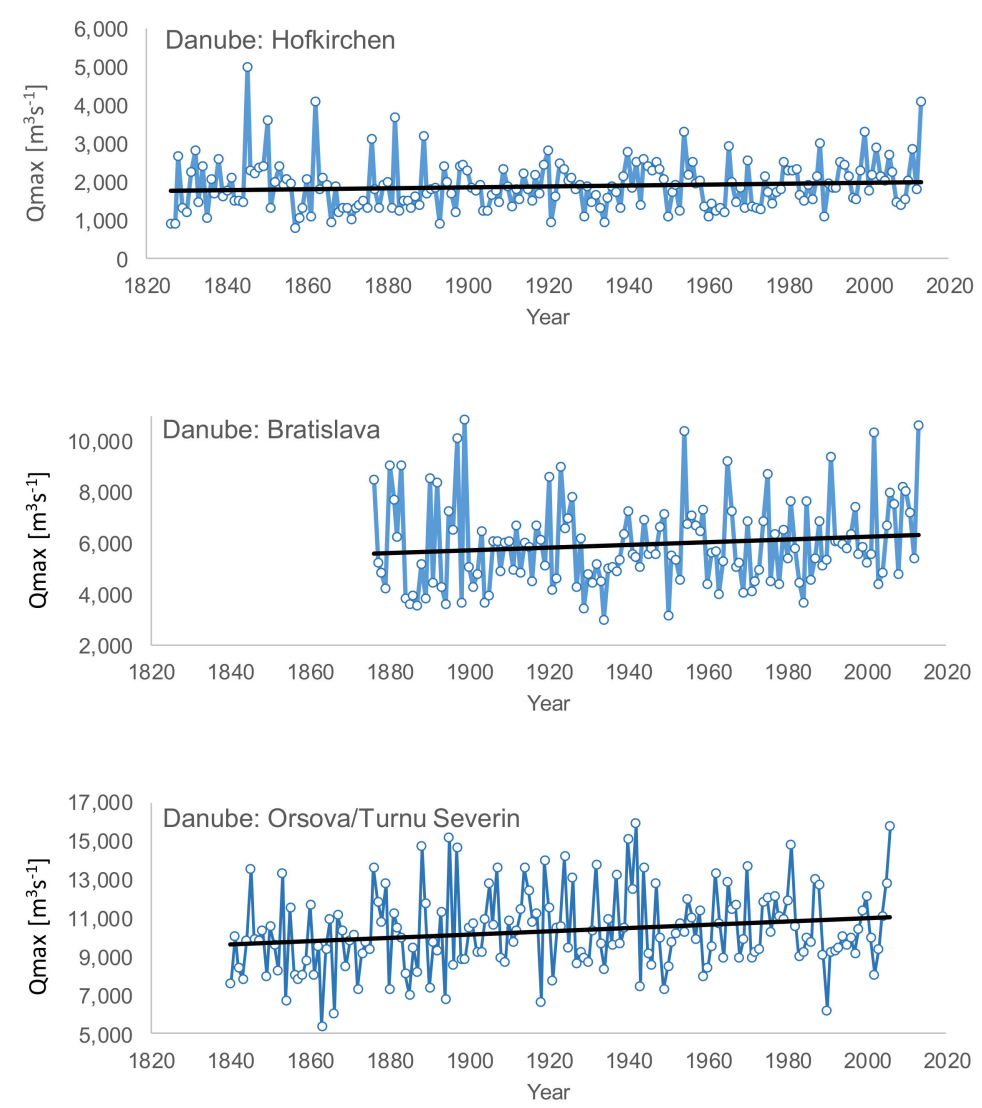

Figure 2. The maximum annual discharge series for selected gauging stations located in the upper, middle and lower Danube (with long data series). 
Floods on the upper (from the source to Bratislava), central, and lower Danube (from Orsova to the Black Sea) do not generally occur simultaneously. For example, the floods that occurred in 1899, 1954 and August 2002 can be characterized as especially extreme for the upper Danube. On the other hand, the floods that occurred in 1895, 1940, 1942, 1970, 1980 and 1981 can be characterized as especially extreme for the lower Danube. The floods that occurred in 1897, 1965, 2006 and 2013 can be characterized as extreme for the entire length of the Danube River. Figure 3a illustrates the course of the extreme floods that occurred in 1942, 1954, 1981 and August 2002, and Figure 3b illustrates the course of the extreme floods that occurred in 1965, 2006 and 2013.

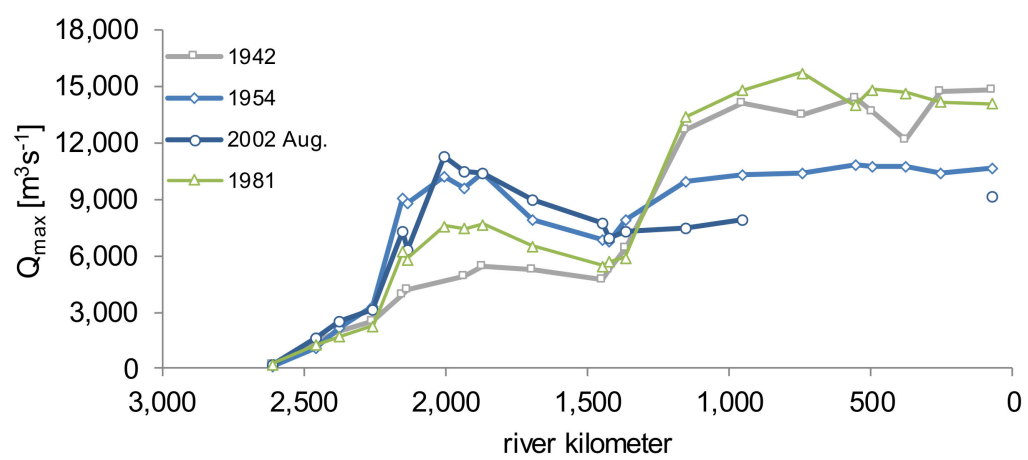

(a)

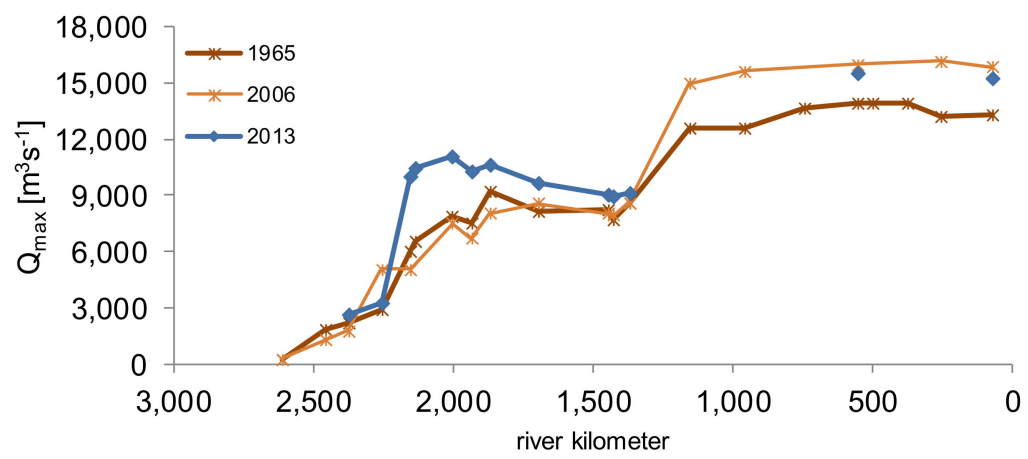

(b)

Figure 3. Course of various extreme floods along the Danube River: (a) floods in 1954, August 2002 on the upper Danube and floods in 1942, 1981 on the lower Danube; (b) floods in 1965, 2006 and 2013 along the entire length of the Danube River.

According to [3], the largest peak discharge on the upper Danube at Vienna was estimated to have a value of $14,000 \mathrm{~m}^{3} \mathrm{~s}^{-1}$ (the year 1501). During the period of 1900-2013, the largest peak discharge was measured on the upper Danube at Kienstock $\left(11,450 \mathrm{~m}^{3} \mathrm{~s}^{-1}\right.$ in 2013) and on the lower Danube at Ceatal Izmail $\left(15,900 \mathrm{~m}^{3} \mathrm{~s}^{-1}\right.$ in 2006).

\subsection{Methods}

\subsubsection{Log-Pearson III Probability Distribution}

For the estimation of the $Q_{\max }$ discharge series distribution function, we used LogPearson Type III distribution. The LPIII distribution is used to estimate the extremes in many natural processes and is the most commonly used frequency distribution, especially in hydrology. The Log-likelihood function of LPIII with estimation of its parameters was developed in [27]. In [43], a frequency factor-based method for hydrological frequency analysis for the random generation of five distributions (normal, lognormal, extreme value type 1, Pearson Type III and Log-Pearson Type III) is presented. The LPIII distribution was also used in flood frequency analysis in $[28,33,34]$. Use of one type of distribution also allows the value of the $T$-year maximum discharges to be estimated for parts of the river 
without observations on the basis of the long-term average of maximum annual discharge and distribution parameters from the neighboring gauging stations.

To estimate the distribution parameters, the method described in the Interagency Committee on Water Data Bulletin 17B [44] was used. Bulletin 17B provided revised procedures for weighting station skew values with results from a generalized skew study, detecting and treating outliers, making two station comparisons and computing the confidence limits of the frequency curve. Flood estimation procedures in the United States traditionally use two primary methods: frequency analysis of peak discharges for floodplain management and levee design, and deterministic Probable Maximum Flood estimates for the design of dams and nuclear facilities, [45].

The Log-Pearson Type III distribution is a three-parameter gamma distribution with a logarithmic transformation of the variable. It is widely used for flood analyses because the data quite frequently fit the assumed annual maximum discharge series. The probability density function of the Pearson Type III distribution is of the following form:

$$
f(x \mid \tau, \alpha, \beta)=\frac{\left(\frac{x-\tau}{\beta}\right)^{\alpha-1} \exp \left(-\frac{x-\tau}{\beta}\right)}{|\beta| \Gamma(\alpha)}
$$

with

$$
\frac{x-\tau}{\beta} \geq 0
$$

where $\tau$ is the location parameter, $\alpha$ is the shape parameter, $\beta$ is the scale parameter and $\Gamma(\alpha)$ is the Gamma function given by Equation (2).

$$
\Gamma(\alpha)=\int_{0}^{\infty} \mathrm{t}^{\alpha-1} \exp (-\mathrm{t}) \mathrm{dt}
$$

The moment method uses the logarithms of variables to estimate the distribution parameters $\log X=\widehat{\mu}+K \widehat{\sigma}$, where $X$ is a random variable, $\widehat{\mu}$ is the mean, $\widehat{\sigma}$ is the standard deviation and $\mathrm{K}$ is a factor of the skew coefficient at a selected exceedance probability.

\subsubsection{Conditions of $Q_{\max }$ Series}

The distribution is fit by computing the base 10 logarithms of the discharge, $Q$, at a selected exceedance probability, P, using the following Equation (3):

$$
\log Q=\bar{X}+K \sigma
$$

where $\bar{X}$ is the mean, $\sigma$ is the standard deviation and $\mathrm{K}$ is a factor of the skew coefficient at selected exceedance probability.

The formulas for these parameters are provided below.

Mean:

$$
\bar{X}=\frac{1}{n} \sum_{i=1}^{n} X_{i}
$$

Standard Deviation:

$$
\sigma=\sqrt{\frac{1}{n-1} \sum_{i=1}^{n}\left(X_{i}-\bar{X}\right)^{2}}
$$

Skew Coefficient:

$$
\mathrm{G}=\frac{\mathrm{n}}{(\mathrm{n}-1)(\mathrm{n}-2) \sigma^{3}} \sum_{\mathrm{i}=1}^{\mathrm{n}}\left(\mathrm{X}_{\mathrm{i}}-\overline{\mathrm{X}}\right)^{3}
$$

The Kolmogorov-Smirnov test was performed to test the assumption that the discharge magnitudes followed the theoretical distributions. The $p$-value $(p \geq 0.05)$ was used as a criterion for rejection of the proposed distribution hypothesis. Probability estimates 
were calculated for the chosen plotting positions. A basic plotting position formula for symmetrical distributions is given by [32]:

$$
p_{i}=\frac{i-\alpha}{n+1-2 \alpha}
$$

where $p_{i}$ is the exceedance probability of variable observations $X_{i}$ ranked from largest $(i=1)$ to smallest $(i=n)$, and $\alpha$ is a plotting position parameter $(0 \leq \alpha \geq 0.5)$.

\subsubsection{Parameter Estimation: Simple Case}

The method of moments uses the logarithms of flood discharges to estimate the distribution parameters. The first three sample moments are used to estimate the LPIII parameters. These include the mean $(\hat{\mu})$, standard deviation $(\hat{\sigma})$, and skew coefficient $(\hat{\gamma})$. In the case where only systematic data are available, with no historical information, the mean, standard deviation, and skew coefficient of the station data may be computed using the following equations:

$$
\begin{gathered}
\hat{\mu}=\frac{1}{n} \sum_{i=1}^{n} X_{i}, \hat{\sigma}=\sqrt{\frac{1}{n-1} \sum_{i=1}^{n}\left(X_{i}-\hat{\mu}\right)^{2}} \\
\hat{\gamma}=\frac{n}{(n-1)(n-2) \hat{\sigma}^{3}} \sum_{i=1}^{n}\left(X_{i}-\hat{\mu}\right)^{3}
\end{gathered}
$$

where $\mathrm{n}$ is the number of flood observations and $\left(^{\wedge}\right)$ represents a sample estimate. The sample standard deviation and skew coefficient include bias correction factors $(n-1)$ and $(\mathrm{n}-1)$. $(\mathrm{n}-2)$ for small samples, respectively.

\subsubsection{Historical Floods}

Historical flood peaks reflect the frequency of large floods and thus should be incorporated into the flood frequency analysis. They can also be used to judge the adequacy of estimated flood frequency relationships. For the latter purpose, appropriate plotting positions or estimates of the average exceedance probabilities associated with the historical peaks and the remainder of the data are desired. An algorithm for assigning plotting positions to censored data, such as historical floods, is provided in [46,47].

\subsubsection{Skew Coefficients in Log-Pearson III Distribution-Regionalization}

The skew coefficient is a measure of the asymmetry of the distribution. There is relatively large uncertainty for the station sample coefficient of skewness (third moment) because it is sensitive to extreme events in records of limited length [48,49]. The station skew coefficient (Gs) and regional skew coefficient can be combined to form a better estimate of skew for a given watershed. Under the assumption that the regional skew coefficient is unbiased and independent of the station skew, the mean-square errors (MSEs) of the station skew and the regional skew can be used to estimate a weighted skew coefficient. If the regional and station skews differ by more than 0.5 , a careful examination of the data and the flood-producing characteristics of the watershed should be made. Greater weight may be given to the station skew depending on record length, the largest floods within the gauging record and watershed, and watershed characteristics. Large deviations between the regional skew and station skew may indicate that the flood frequency characteristics of the watershed of interest are different from those used to develop the regional skew estimate. It is thought that station skew is a function of rainfall skew, channel storage and basin storage [50]. There is considerable variability of responses among different basins with similar observable characteristics, in addition to the random sampling variability in estimating skew from a short record. It is considered reasonable to give greater weight to the station skew, after due consideration of the data and flood-producing characteristics of the basin [49]. 
The estimation of the design discharge values by Log-Pearson III-type probability distribution according to the method described in [44] is presented hereafter. The frequency curve spreadsheet version 3.06 of [44] was used to estimate the parameters of distribution function with exclusion and inclusion of the historical floods data in the calculation. The design discharge values for 20 gauge stations from Germany to Romania along the Danube River were calculated.

\section{Results}

\subsection{Estimation of the T-Year Design Discharges along the Danube River}

As the first step, we estimated the LPIII distribution function parameters (mean $Q$, standard deviation $S$, and station skew coefficient $G$ s) for each of the stations separately and computed the $Q_{T}$ design values. The design values of selected $T$-year annual maximum discharges along the Danube River with station skew coefficients Gs are listed in Table 2.

Table 2. Design values of selected $T$-year annual maximum discharges in $\left[\mathrm{m}^{3} \mathrm{~s}^{-1}\right]$ along the Danube River (R: runoff depth, Gs: station skew coefficient).

\begin{tabular}{|c|c|c|c|c|c|c|c|c|}
\hline $\begin{array}{l}\text { Without Estimated } \\
\text { Historical Maxima }\end{array}$ & $\begin{array}{c}\mathbf{R} \\
{[\mathrm{mm}]}\end{array}$ & Gs & $\begin{array}{c}10 \\
{[\text { Year] }}\end{array}$ & $\begin{array}{c}50 \\
{[\text { Year] }}\end{array}$ & $\begin{array}{c}100 \\
{[\text { Year] }}\end{array}$ & $\begin{array}{c}200 \\
{[\text { Year] }}\end{array}$ & $\begin{array}{c}500 \\
{[\text { Year] }}\end{array}$ & $\begin{array}{c}1000 \\
{[\text { Year] }}\end{array}$ \\
\hline Berg & 296 & -0.30 & 324 & 432 & 476 & 518 & 573 & 613 \\
\hline Ingolstadt & 494 & 0.15 & 1514 & 1891 & 2050 & 2209 & 2421 & 2583 \\
\hline $\begin{array}{l}\text { Regensburg- } \\
\text { Schwabelweis }\end{array}$ & 396 & -0.46 & 2125 & 2530 & 2675 & 2809 & 2969 & 3081 \\
\hline Pfelling & 392 & -0.23 & 2144 & 2649 & 2846 & 3034 & 3273 & 3447 \\
\hline Hofkirchen & 425 & 0.09 & 2356 & 3547 & 3897 & 4250 & 4724 & 5091 \\
\hline Achleiten & 587 & 0.39 & 5486 & 6835 & 7422 & 8020 & 8835 & 9473 \\
\hline Linz & 581 & 0.26 & 4641 & 7352 & 8205 & 9092 & 10,323 & 11,304 \\
\hline Stein-Krems (Kienstock) & 621 & 0.39 & 7397 & 9605 & 10,592 & 11,613 & 13,028 & 14,154 \\
\hline Wien-Nussdorf & 596 & 0.27 & 7187 & 9046 & 9847 & 10,658 & 11,756 & 12,610 \\
\hline Devin/Bratislava & 492 & 0.18 & 8116 & 10,273 & 11,192 & 12,119 & 13,365 & 14,328 \\
\hline Nagymaros & 401 & -0.05 & 7325 & 8712 & 9257 & 9783 & 10,457 & 10,955 \\
\hline Mohács & 355 & -0.08 & 6548 & 7708 & 8157 & 8589 & 9138 & 9541 \\
\hline Bezdan & 354 & 0.30 & 6452 & 7847 & 8437 & 9029 & 9823 & 10,435 \\
\hline Bogojevo & 363 & 0.19 & 7334 & 8810 & 9418 & 10,020 & 10,815 & 11,418 \\
\hline Pancevo & 320 & 0.15 & 12,611 & 14,661 & 15,483 & 16,285 & 17,326 & 18,105 \\
\hline Veliko Gradiste & 307 & 0.02 & 13,128 & 15,167 & 15,962 & 16,728 & 17,708 & 18,430 \\
\hline Orsova-Turnu Severin & 307 & -0.19 & 12,901 & 14,754 & 15,445 & 16,094 & 16,901 & 17,481 \\
\hline Zimnicea & 288 & -0.09 & 13,776 & 15,769 & 16,528 & 17,248 & 18,155 & 18,815 \\
\hline Reni & 262 & -0.40 & 13,918 & 15,596 & 16,183 & 16,715 & 17,352 & 17,793 \\
\hline Ceatal Izmail & 251 & -0.21 & 13,677 & 15,492 & 16,161 & 16,785 & 17,557 & 18,108 \\
\hline
\end{tabular}

In the case of gauges for which some historical maxima were known, we added the historical data in the calculation. Next, the parameters of the LPIII distribution curves were recalculated for individual stations. The design values of selected $T$-year annual maximum discharges along the Danube River with historical skew coefficients Gh are presented in Table 3.

Table 3. Design values of selected $T$-year annual maximum discharges in $\left[\mathrm{m}^{3} \mathrm{~s}^{-1}\right]$ along the Danube River (R: runoff depth, Gh: historical skew coefficient).

\begin{tabular}{|c|c|c|c|c|c|c|c|c|}
\hline $\begin{array}{l}\text { With Estimated } \\
\text { Historical Maxima }\end{array}$ & Gh & $\begin{array}{c}10 \\
{[\text { Year] }}\end{array}$ & $\begin{array}{c}50 \\
{[\text { Year] }}\end{array}$ & $\begin{array}{c}100 \\
{[\text { Year] }}\end{array}$ & $\begin{array}{c}200 \\
{[\text { Year] }}\end{array}$ & $\begin{array}{c}500 \\
{[\text { Year] }}\end{array}$ & $\begin{array}{c}1000 \\
{[\text { Year] }}\end{array}$ & $\begin{array}{c}\text { Year of } \\
\text { Historical Max. }\end{array}$ \\
\hline $\begin{array}{l}\text { Regensburg- } \\
\text { Schwabelweis }\end{array}$ & 0.40 & 2306 & 3140 & 3525 & 3931 & 4505 & 4970 & $\begin{array}{c}1845,1850,1862 \\
1882,2013\end{array}$ \\
\hline Pfelling & 0.45 & 2320 & 3224 & 3651 & 4105 & 4756 & 5290 & $\begin{array}{c}1845,1862,1850 \\
1882,2013\end{array}$ \\
\hline
\end{tabular}


Table 3. Cont.

\begin{tabular}{ccccccccc}
\hline $\begin{array}{c}\text { With Estimated } \\
\text { Historical Maxima }\end{array}$ & $\mathbf{G h}$ & $\begin{array}{c}\mathbf{1 0} \\
\text { [Year] }\end{array}$ & $\begin{array}{c}\mathbf{5 0} \\
\text { [Year] }\end{array}$ & $\begin{array}{c}\mathbf{1 0 0} \\
\text { [Year] }\end{array}$ & $\begin{array}{c}\mathbf{2 0 0} \\
\text { [Year] }\end{array}$ & $\begin{array}{c}\mathbf{5 0 0} \\
\text { [Year] }\end{array}$ & $\begin{array}{c}\mathbf{1 0 0 0} \\
\text { [Year] }\end{array}$ & $\begin{array}{c}\text { Year of } \\
\text { Historical Max. }\end{array}$ \\
\hline Achleiten & 1.17 & 5778 & 7754 & 8710 & 9743 & 11,244 & 12,495 & $1862,1899,2013$ \\
Linz & 0.76 & 4621 & 7880 & 9027 & 10,276 & 12,104 & 13,639 & 1501 \\
Stein-Krems (Kienstock) & 0.71 & 7545 & 10,255 & 11,554 & 12,952 & 14,974 & 16,650 & $1501,1787,2013$ \\
Wien-Nussdorf & 0.64 & 7328 & 9620 & 10,678 & 11,792 & 13,366 & 14,642 & $1501,1787,2013$ \\
Devin/Bratislava & 0.24 & 8194 & 10,485 & 11,477 & 12,487 & 13,860 & 14,931 & 1501,1787 \\
Nagymaros & 0.06 & 7421 & 8955 & 9574 & 10,182 & 10,975 & 11,570 & 2013 \\
Mohács & 0.04 & 6658 & 7966 & 8491 & 9004 & 9669 & 10,167 & 2013 \\
Reni & 0.05 & 14,156 & 16,485 & 17,403 & 18,291 & 19,434 & 20,281 & 1897 \\
Ceatal Izmail & -0.03 & 13,816 & 15,905 & 16,712 & 17,484 & 18,466 & 19,186 & 1876 \\
\hline
\end{tabular}

The inclusion of the historic flood data in the calculation increased the skew coefficient by an average of 0.22 . The highest difference between skew coefficients with and without historical data was 0.87 for the Regensburg-Schwabelweis station. An example of the computation of theoretical LPIII exceedance probability curves of the Danube maximum annual discharges, without historical data and with historical data for Regensburg-Schwabelweis, Stein-Krems, Devin/Bratislava, and Ceatal Izmail, are illustrated in Figure 4.
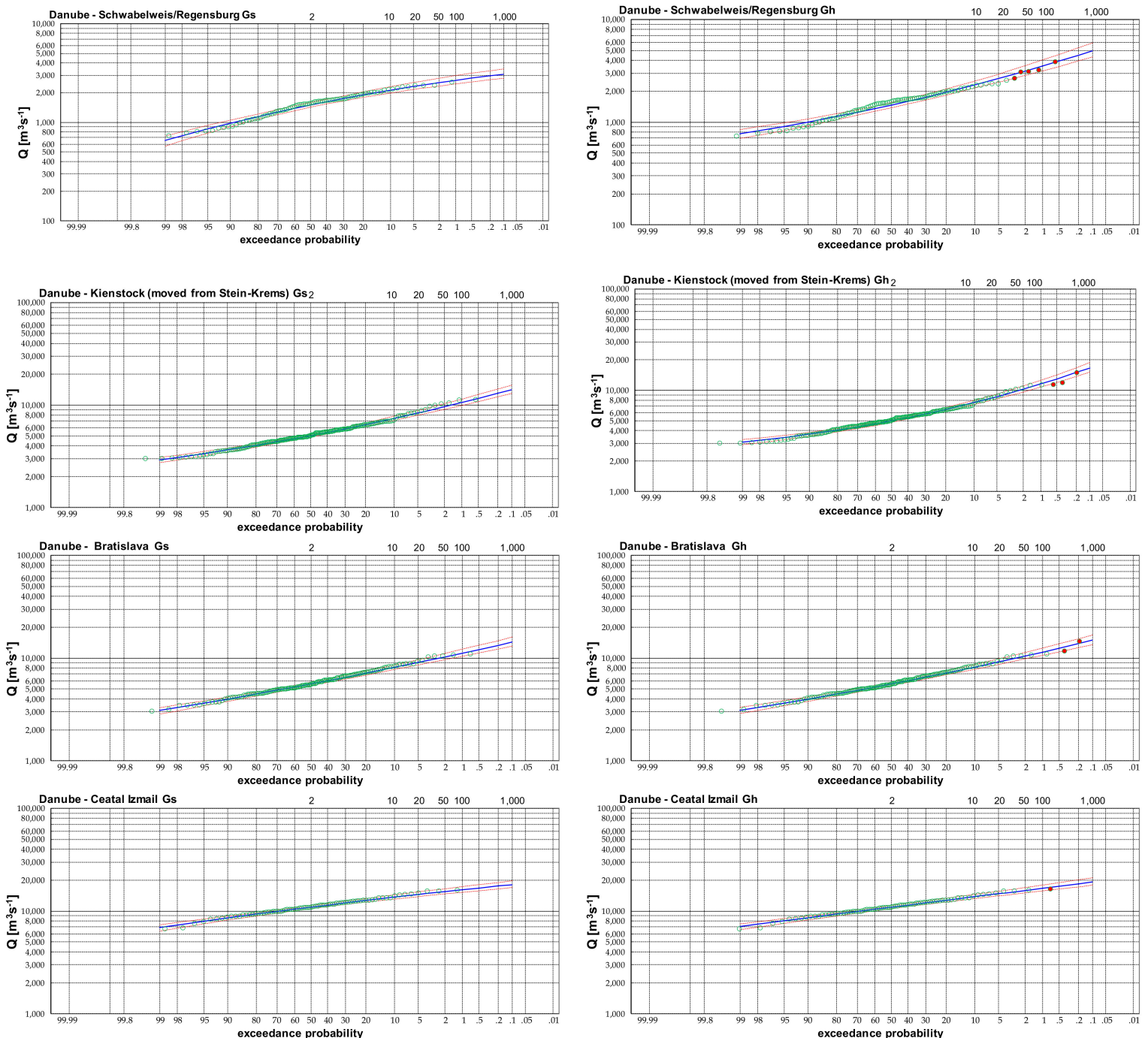

Figure 4. Examples of the theoretical LPIII exceedance probability curves of the Danube maximum annual discharges without historical data (left) and with historical data (red points, right). 
Differences in the estimation of the maximum discharges with a return period of 100 and 1000 years along the Danube River, estimated according to LPIII distribution with historical data and without historical data for each of the stations, are illustrated in Figure 5a,b. The average difference between the estimated maximum discharges in gauging stations, with or without the inclusion of the historical data for a return period of $T=100$, was $751 \mathrm{~m}^{3} \mathrm{~s}^{-1}$ and for a return period of $T=1000$ years was $1730 \mathrm{~m}^{3} \mathrm{~s}^{-1}$. Our investigation showed that the inclusion of historical floods changed the curvature of the LPIII distribution curves and changed the design discharge.

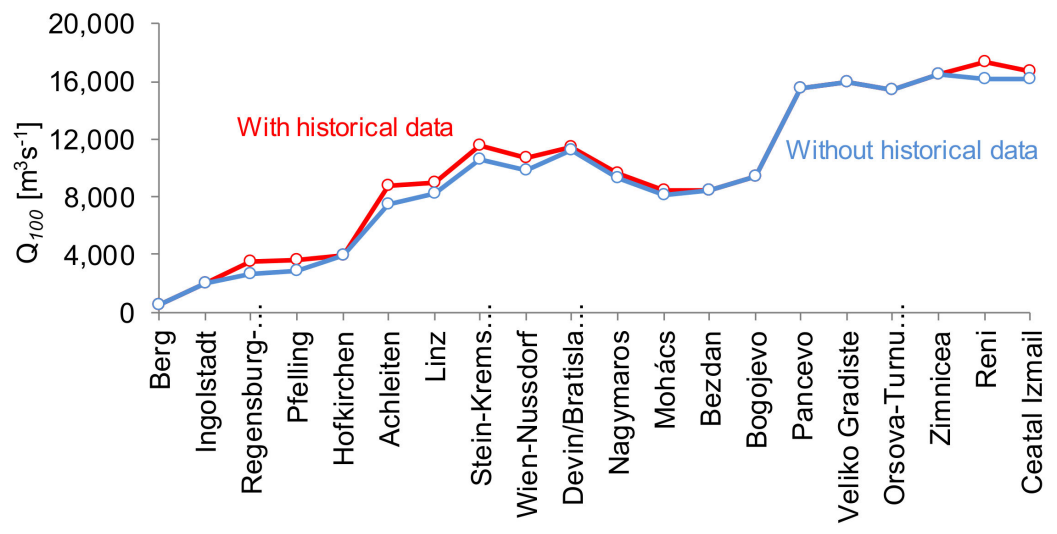

(a)

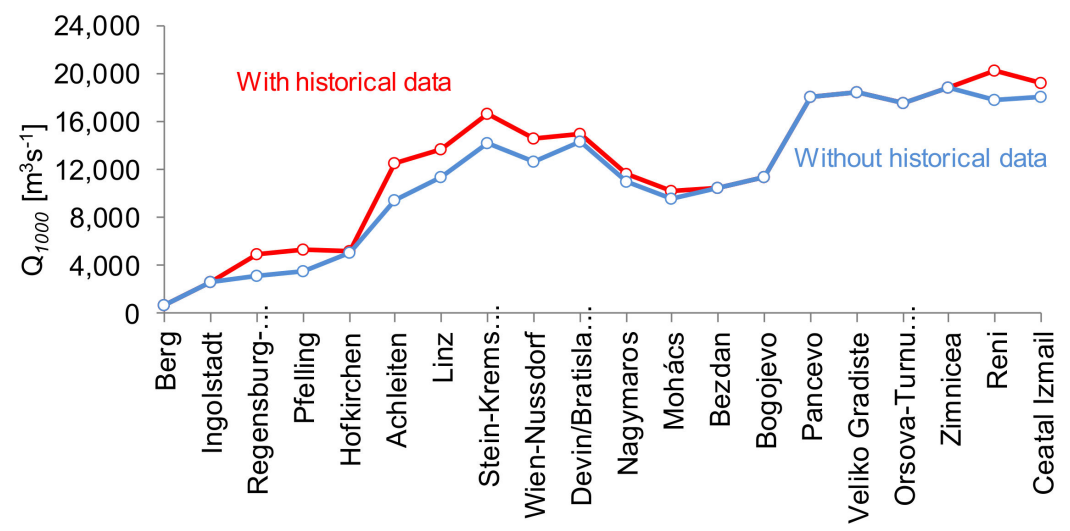

(b)

Figure 5. Differences in the estimated maximum discharges with return periods of (a) 100 years and (b) 1000 years along the Danube River, estimated according to LPIII distribution with historical data (11 red points) and without historical data (20 blue points).

\subsection{Regionalization of the Skew Coefficients of the LPIII Probability Curves for the Danube River}

The previous part of the analyzed annual maximum discharges shows how the $Q_{T}$ design values change along the Danube River. The ratio $k$ of $Q_{T} / Q_{a}$ (Qa: long-term mean discharges) for selected stations are presented in Figure 6a. The 1000-year discharge is 15 times higher than the mean annual discharge at the Berg station, seven times higher at the Bratislava station, and only three times at the Reni station. Subsequently, we individually plotted the course of the skew parameter Gs for each station (Figure 6b). 


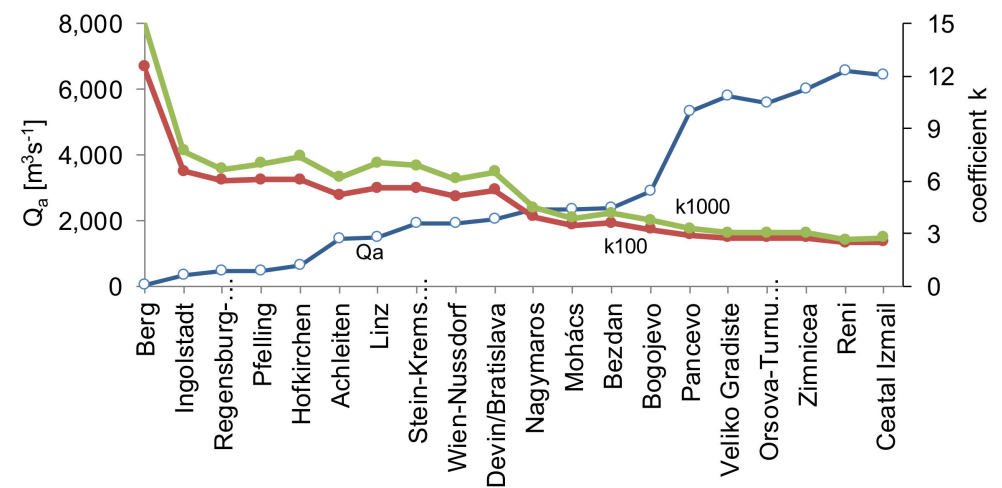

(a)

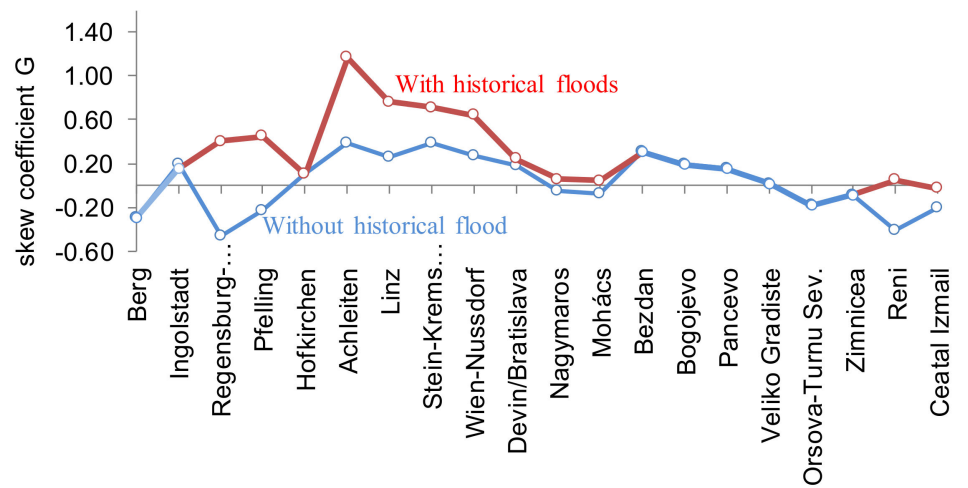

(b)

Figure 6. The course of the (a) ratio $\mathrm{k}$ of $\mathrm{Q}_{T} / \mathrm{Q}_{\mathrm{a}}$ at gauge stations along the Danube River, and (b) station skew coefficient $\mathrm{G}$ with and without historical floods along the Danube River.

Within the regionalization, we investigated various dependences of the skew coefficient Gs, individual physical-geographical characteristics (river basin area, altitude of the station), and runoff depth at stations along the Danube River. The equations computed from the regression analyses could then be used to calculate flood-discharge estimates at sites where the basin characteristics were known, but for which no discharge data were available. The course of the long-term runoff depth $\mathrm{R}$ ( $\mathrm{mm}$ per year) along the Danube River is illustrated in Figure 7. Figure $6 \mathrm{~b}$ or Figure 7 show that both skew coefficients Gs and Gh have a similar course as related to long-term runoff depth $\mathrm{R}$ at the analyzed stations. Therefore, we primarily analyzed the relationships between the skew coefficient and the runoff depth $\mathrm{R}$ (Figure $8 \mathrm{a}, \mathrm{b}$ ).

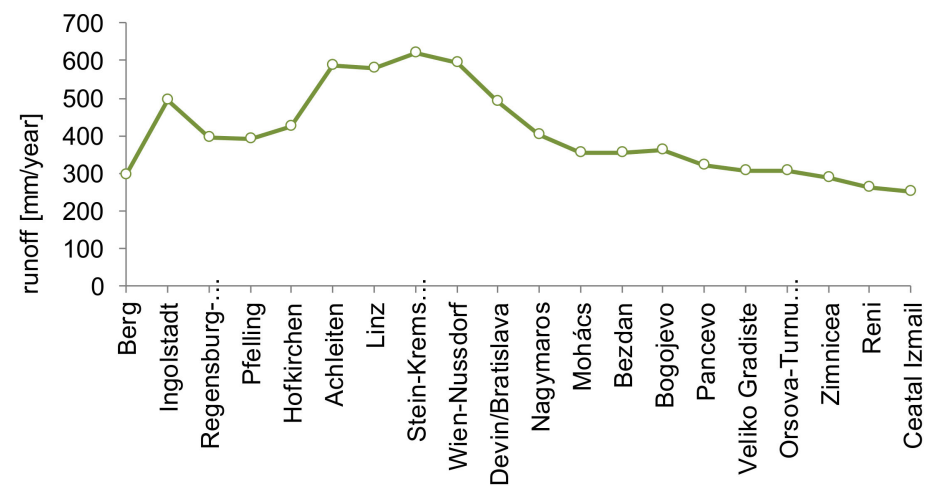

Figure 7. Course of the long-term runoff depth $\mathrm{R}$ (mm per year) along the Danube River. 


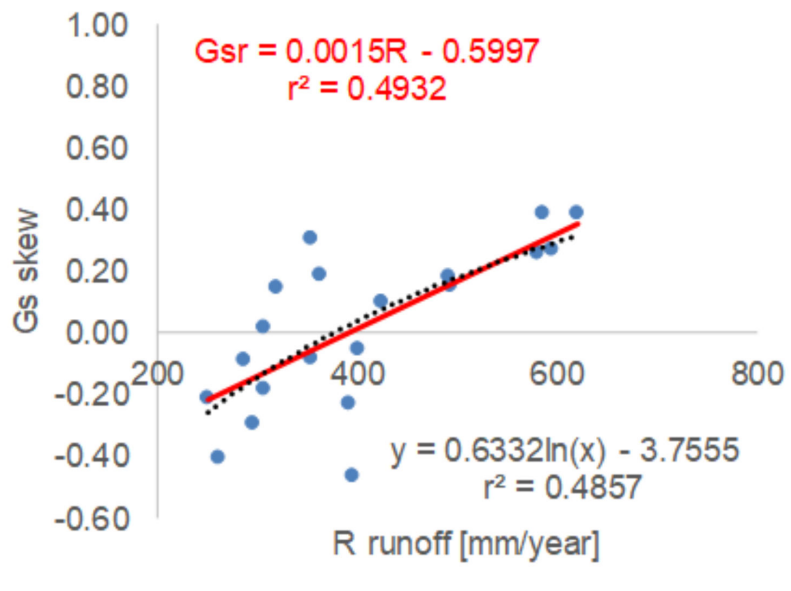

a)

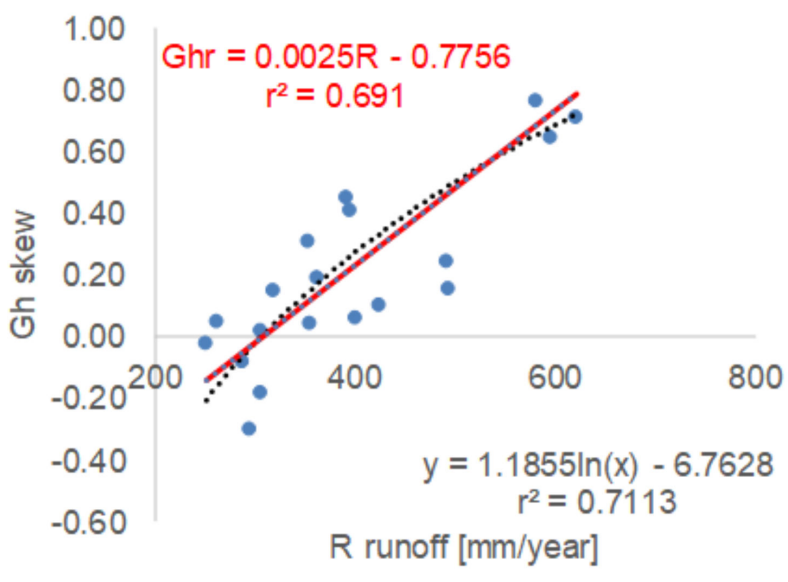

Figure 8. Dependence of the skew coefficient $G$ on the runoff depth at Danube River gauges: (a) Gs: without historical floods; (b) Gh: with historical floods in some gauging stations.

After estimating the best fitted relationship for the Danube River stations, we propose using the generalized (regional) skew coefficient Ghr calculated according to the following relation (11):

$$
\mathrm{Ghr}=0.0025 \mathrm{R}-0.7756
$$

where Ghr denotes the regional (generalized) skew coefficient with some historical data, and $\mathrm{R}$ denotes the long-term runoff depth (from ca. 260 to ca. $600 \mathrm{~mm}$ per year).

An example of the regression Equation (11) being applied to calculate the regionalized skew parameters Ghr for the Danube River at Hofkirchen is presented herein. The station skew coefficient Gs of the selected station was relatively low. Such skew parameter values meant that the upper curvature of the LPIII exceedance probability curves did not capture extreme values. An example of the computation of theoretical LPIII exceedance probability curves of the Danube at Hofkirchen with station skew parameter Gs, and regionalized parameter Ghr, is shown in Figure 9. 
a)
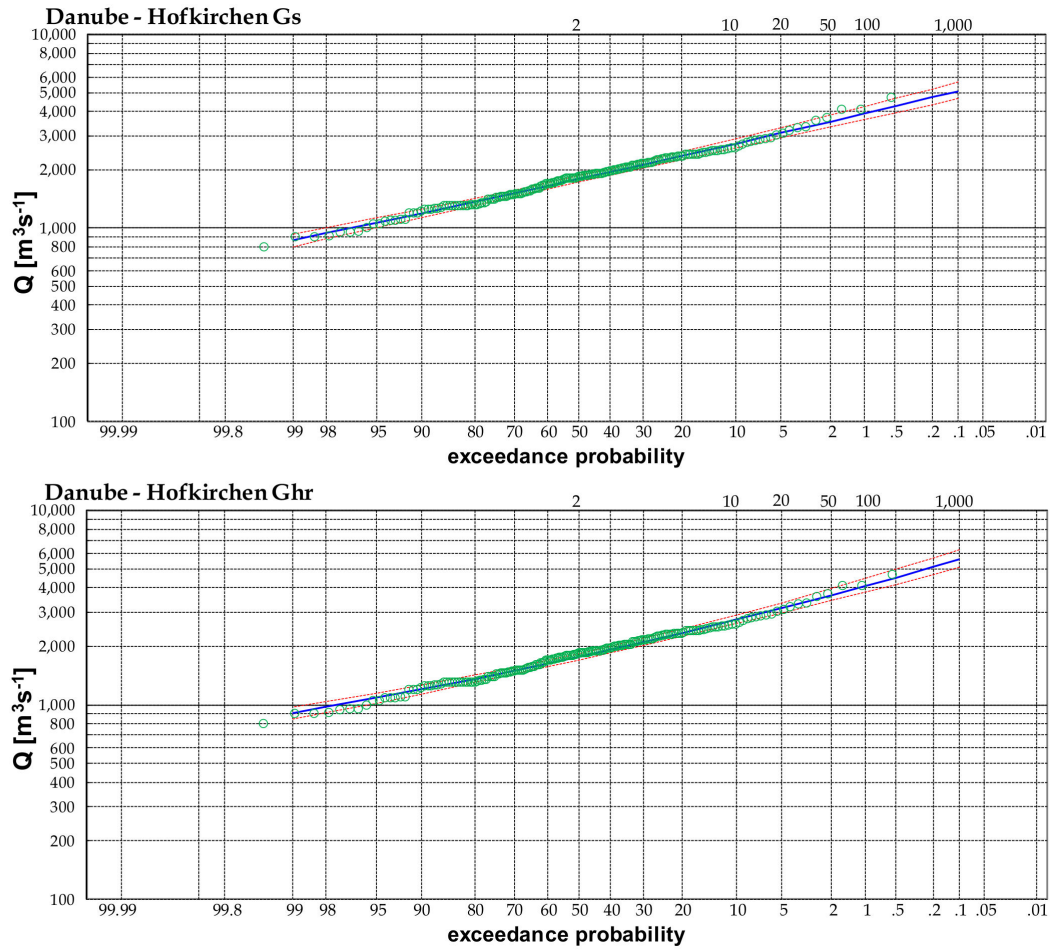

b)

Figure 9. Examples of the theoretical LPIII exceedance probability curves of the Danube maximum annual discharges with (a) station skew parameter Gs and (b) regionalized skew parameter Ghr for the Danube at Hofkirchen.

\section{Discussion}

The flow regime conditions of the Danube River are continually changing. Urbanization, channel regulation, flood protection measures and many other factors can change the maximum discharges, the water level and/or the travel time of floods. The travel time of the big flood waves between Hofkirchen $(2257 \mathrm{rkm})$ and Passau $(2226.7 \mathrm{rkm})$ is $25 \mathrm{~h}$, with an average celerity of $30 \mathrm{~km} /$ day. The travel time of the wave between Passau (2226 rkm) and Bratislava (1869 rkm) was $96 \mathrm{~h}$ in 2002 (with a wave celerity of $89 \mathrm{~km} /$ day), and $130 \mathrm{~h}$ in 1954 (with a wave celerity of $66 \mathrm{~km} /$ day). Examples of the travel times of the important floods between Passau and Nagymaros are presented in Figure 10a. The travel time of the largest floods between Bratislava $(1869 \mathrm{rkm})$ and Orsova $(955 \mathrm{rkm})$ is around 16 days, with an average celerity of $57 \mathrm{~km} /$ day. According to [51], the time difference between the large floods at Orsova and the mouth of the Black Sea is 15-20 days, when the flood wave travels along the Danube River with an average celerity of about $53 \mathrm{~km} /$ day.

The volume of transported suspended load and bed load has gradually decreased in the middle reach of the Danube due to the construction of the reservoirs on the German and Austrian reach. The new Danube dam near Čuňovo increased the Danube water level at Bratislava after November 1992, and the cessation of gravel excavation below Bratislava in 1980 caused an increase in water levels corresponding to the same flood flow observed in the past (Figure 10b) [52].

Monitoring and evaluation of extreme hydrological phenomena using various methods and models is very important, as anthropogenic activities can negatively affect the application of frequency analyses. It is vital to have complete flood regime data to be able to generalize such information on the basis of long-term observations from basins. We consider the plotting of flood risk maps for these extreme hydrological situations to be necessary regardless of the Directive 2007/60/EC of the European Parliament. Determining design values for extreme floods with a long return period (once every 100, 500 or 1000 years) is a complex process with great levels of uncertainty. 


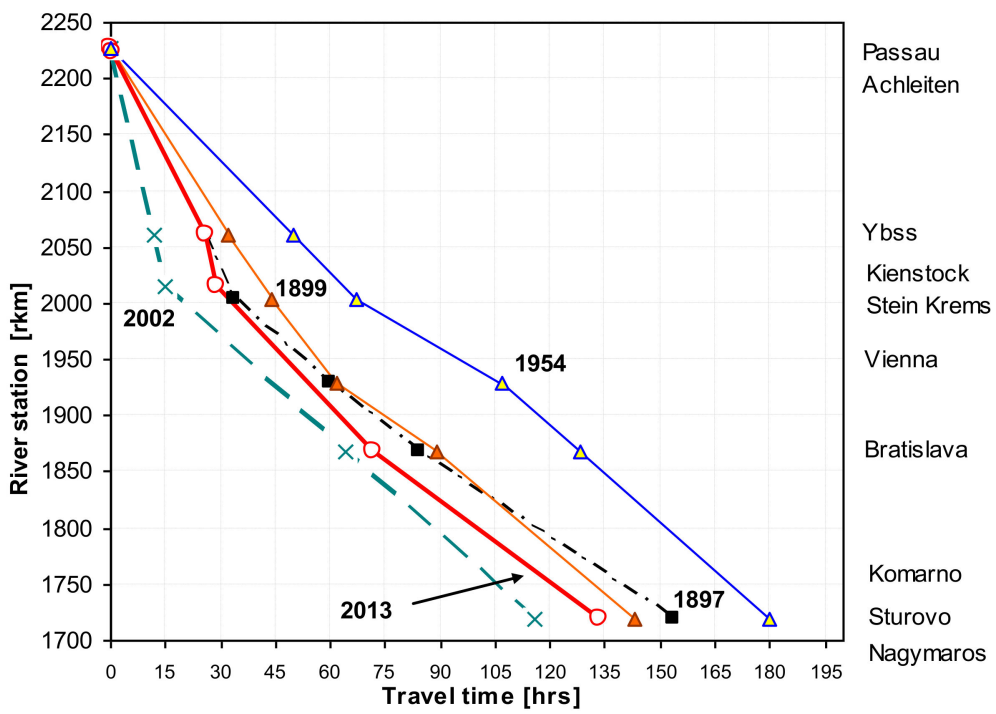

a)

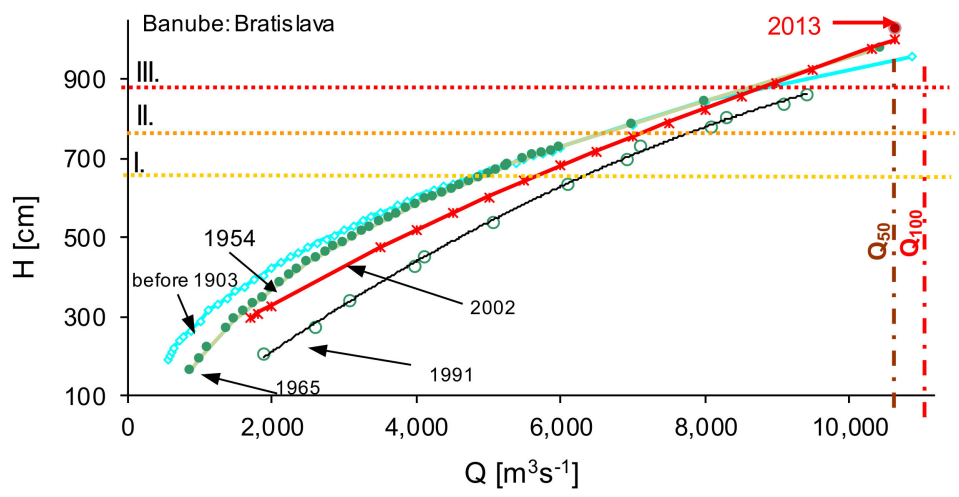

b)

Figure 10. (a) Travel times of selected floods, and (b) comparison of rating curves of the Danube River at Bratislava (red point: maximum hydrological values of the flood in June 2013).

Assessing the design discharges along the Danube channel is also complicated by the different estimation methods in various countries. Therefore, it is necessary to harmonize flood design value assessment methods. The authors in [53] summarized the regionalization of distribution functions estimated for annual peak discharges in the Danube basin based on regional empirical relationships from sufficiently long and reliable series of annual peak discharges available for 176 water gauging stations in the Danube catchment. The aim was to facilitate the estimation of the quantile of annual peak discharge and the related specific flood discharges in the ungauged river sections of that catchment.

Our paper presents another possible approach for determining the design values of the $T$-year floods with very long return periods along the Danube River. We tested and used a uniform methodology to estimate the design values of flood discharges in 20 stations along the Danube River to harmonize the methodology for design discharge value estimation in stations along the Danube. The Log-Pearson type III distribution was selected for its flexibility and because it can be used with extreme values according to the coefficient of skewness (G). Using one type of distribution made it possible to generalize its skewness coefficients. Thereafter, we were able to estimate $T$-year discharges at gauges with short observation period, and at sites between gauges. The first results showed that the station skew parameter Gs indicated high positive values at the Danube River stations with low infiltrating areas, quick propagation of flood waves, and one or more extremely high peak discharge. On the other hand, the station skew parameter Gs indicated negative values at the Danube River stations with a higher share of infiltrating areas and runoff from 
catchment regulated by lakes and wetlands. Previous experiences with the occurrence of extreme floods also showed that the historical flood events need to be included in the latest calculations when estimating the threat of such events. For the Danube River, we can see how the inclusion of historical floods in the measured data series can change the estimation of the discharge values with return periods from 100 to 1000 years. The results showed that the inclusion of historical floods can change and increase the design discharge. The authors in [54] assessed the added value of using historical data for flood quantile estimation, and their results showed that using historical flood information improved both the reliability and stability of the design flood estimates.

\section{Conclusions}

The Log-Pearson III distribution fits well with the observed data, and it is an appropriate mathematical tool for estimating the design values with long return periods.

The skew parameter and its optimal setting for the gauging station is sufficient in many cases; however, in practice, this may not be sufficient when considering a short data series or a data series from a period without historical data or a recent significant extreme.

An alternative method for estimating the design values in basins without extremes is to use the generalized skew parameter derived from a data series from basins with similar runoff regimes where the extremes are known or captured.

Our investigation showed that the regional skew parameter curved the LPIII distribution curves to capture all discharges with low probability of occurrence with confidence intervals $\mathrm{Q}_{5 \%}-\mathrm{Q}_{95 \%}$.

For cases in which the extreme value was included in the analyzed period and the long-term runoff depth was lower, the station's historical skew parameter achieved a better curvature for the LPIII distribution curve.

An important conclusion of this study relates to how local conditions and datasets at gauging stations can determine the magnitude of discharge uncertainty and how the discharge uncertainty changes according to time and magnitude. The results of this study can be applied to investigate and improve the estimation of the design discharges of ungauged or poorly gauged rivers within the Danube River Basin. In frequency analyses, it is again important to note that the process is never-ending and, if anything, will change according to catchment. Thus, it is necessary to recalculate distribution curves and define new design discharges for recent periods for particular stations.

Author Contributions: Conceptualization, V.B.M.; formal analysis, V.B.M. and P.P.; investigation, V.B.M. and P.P.; writing-original draft, V.B.M.; writing-review \& editing, P.P., D.H. and P.M. All authors have read and agreed to the published version of the manuscript.

Funding: This research received no external funding.

Institutional Review Board Statement: Not applicable.

Informed Consent Statement: Not applicable.

Data Availability Statement: Data sharing is not applicable.

Acknowledgments: This work was supported by the project VEGA No. 2/0004/19 "Analysis of changes in surface water balance and harmonization of design discharge calculations for estimation of flood and drought risks in the Carpathian region".

Conflicts of Interest: The authors declare no conflict of interest.

\section{References}

1. Fernández, L.; Scherer, M.; Emil, J. Gumbel's last course on the "Statistical theory of extreme values": A conversation with Tuncel, M. Yegulalp. Extremes 2018, 21, 97-113. [CrossRef]

2. Gumbel, E.J. Statistical Theory of Extreme Values and Some Practical Applications; Applied Mathematics Series; US Government Printing Office: Washington, DC, USA, 1954; 60p.

3. Kresser, W. The Flooding of the Danube; Springer Verlag: Vienna, Austria, 1957; 95p. (In German) 
4. Merz, R.; Blöschl, G. Flood frequency hydrology: 1. Temporal, spatial, and causal expansion of information. Water Resour. Res. 2008, 44, 08432. [CrossRef]

5. Merz, R.; Blöschl, G. Flood frequency hydrology: 2. Combining data evidence. Water Resour. Res. 2008, 44, 08433. [CrossRef]

6. Elleder, L. Reconstruction of the 1784 flood hydrograph for the Vltava River in Prague, Czech Republic. Glob. Planet. Chang. 2010, 70, 117-124. [CrossRef]

7. Elleder, L.; Herget, J.; Roggenkamp, T.; Niesen, A. Historic floods in the city of Prague-A reconstruction of peak discharges for 1481-1825 based on documentary sources. Hydrol. Res. 2012, 44, 202-214. [CrossRef]

8. Kjeldsen, T.; Macdonald, N.; Lang, M.; Mediero, L.; Albuquerque, T.; Bogdanowicz, E.; Brázdil, R.; Castellarin, A.; David, V.; Fleig, A.; et al. Documentary evidence of past floods in Europe and their utility in flood frequency estimation. J. Hydrol. 2014, 517, 963-973. [CrossRef]

9. Strupczewski, W.G.; Kochanek, K.; Bogdanowicz, E. Historical floods in flood frequency analysis: Is this game worth the candle? J. Hydrol. 2017, 554, 800-816. [CrossRef]

10. Wetter, O. The potential of historical hydrology in Switzerland. Hydrol. Earth Syst. Sci. 2017, 21, 5781-5803. [CrossRef]

11. Brázdil, R.; Kundzewicz, Z.W.; Benito, G. Historical hydrology for studying flood risk in Europe. Hydrol. Sci. J. 2006, 51, 739-764. [CrossRef]

12. Pekárová, P.; Miklánek, P.; Melo, M.; Halmová, D.; Pekár, J.; Bačová Mitková, V. Flood Marks along the Danube River between Passau and Bratislava; Veda: Bratislava, Slovakia, 2014; 102p, ISBN 978-80-224-1408-1.

13. Szolgay, J.; Kohnová, S.; Hlavčová. Uncertainties in determining the design flood. Environment 2003, 37, 194-199. (In Slovak)

14. Rogger, M.; Kohl, B.; Pirkl, H.; Viglione, A.; Komma, J.; Kirnbauer, R.; Merz, R.; Blöschl, G. Runoff models and flood frequency statistics for design flood estimation in Austria-Do they tell a consistent story? J. Hydrol. 2012, 456-457, 30-43. [CrossRef]

15. Coxon, G.; Freer, J.; Westerberg, I.K.; Wagener, T.; Woods, R.; Smith, P.J. A novel framework for discharge uncertainty quantification applied to 500 UK gauging stations. Water Resour. Res. 2015, 51, 5531-5546. [CrossRef] [PubMed]

16. Lam, D.; Thompson, C.; Croke, J.; Sharma, A.; Macklin, M.; Thompson, C. Reducing uncertainty with flood frequency analysis: The contribution of paleoflood and historical flood information. Water Resour. Res. 2017, 53, 2312-2327. [CrossRef]

17. Šraj, M.; Viglione, A.; Parajka, J.; Blöschl, G. The influence of non-stationarity in extreme hydrological events on flood frequency estimation. J. Hydrol. Hydromech. 2016, 64, 426-437. [CrossRef]

18. Leščešen, I.; Dolinaj, D. Regional Flood Frequency Analysis of the Pannonian Basin. Water 2019, 11, 193. [CrossRef]

19. Stănescu, V.A. Regional Analysis of the Annual Peak Discharges in the Danube Catchment. Follow-Up Volume No.VII to the Danube Monograph; Regional Cooperation of the Danube Countries: Bucharest, Romania, 2004; 64p.

20. Cunnane, C. Statistical distributions for flood frequency analysis. In Operational Hydrology Report (WMO); WMO: Geneva, Switzerland, 1989.

21. Helsel, D.R.; Hirsch, R.M. Statistical Methods in Water Resources; U.S. Geological Survey: Reston, VA, USA, $2002 ;$ Volume 323.

22. Flynn, K.M.; Kirby, W.H.; Hummel, P.R. User's Manual for Program PeakFQ Annual Flood-Frequency AnalysisUsing Bulletin 17B Guidelines; Chapter B4; U.S. Geological Survey: Reston, VA, USA, 2006; p. 42.

23. Khosravi, G.; Majidi, A.; Nohegar, A. Determination of suitable probability distribution for annual mean and peak discharges estimation (Case study: Minab river-Barantin gauge, Iran). Int. J. Probab. Stat. 2012, 1, 160-163. [CrossRef]

24. Langat, P.K.; Kumar, L.; Koech, R. Identification of the Most Suitable Probability Distribution Models for Maximum, Minimum, and Mean Streamflow. Water 2019, 11, 734. [CrossRef]

25. Koutsoyiannis, D. Uncertainty, entropy, scaling and hydrological statistics. Hydrol. Sci. J. 2005, 50, 381-404.

26. Bobée, B. The Log Pearson type 3 distribution and its application in hydrology. Water Resour. Res. 1975, 11, 681-689. [CrossRef]

27. Pilon, P.J.; Adamowski, K. Asymptotic variance of flood quantile in log Pearson Type III distribution with historical information. J. Hydrol. 1993, 143, 481-503. [CrossRef]

28. Griffis, V.W.; Stedinger, J.R. The Log-Pearson type III distribution and its application in flood frequency analysis. I: Distribution characteristics. J. Hydrol. Eng. 2007, 12, 482-491.

29. Pawar, U.; Hire, P. Flood Frequency Analysis of the Mahi Basin by Using Log Pearson Type III Probability Distribution. Hydrospatial Anal. 2018, 2, 102-112. [CrossRef]

30. Phien, H.N.; Ajirajah, T.J. Applications of the log Pearson type-3 distribution in hydrology. J. Hydrol. 1984, 73, 359-372. [CrossRef]

31. Cohn, T.A.; Stedinger, J.R. Use of historical information in a maximum-likelihood framework. J. Hydrol. 1987, 96, 215-223. [CrossRef]

32. Stedinger, J.R.; Vogel, R.M.; Foufoula-Georgiou, E. Frequency analysis of extreme events. In Handbook of Hydrology; Maidment, D.R., Ed.; McGraw-Hill: New York, NY, USA, 1993; Chapter 18.

33. Griffis, V.W.; Stedinger, J.R. The Log-Pearson type III distribution and its application in flood frequency analysis. II: Parameter Estimation Methods. J. Hydrol. Eng. 2007, 12, 492-500. [CrossRef]

34. Griffis, V.W.; Stedinger, J.R. Log-Pearson type 3 distribution and its application in flood frequency analysis, III-sample skew and weighted skew estimators. J. Hydrol. Eng. 2009, 14, 121-130. [CrossRef]

35. Millington, N.; Das, S.; Simonovic, S.P. The Comparison of GEV, Log-Pearson Type 3 and Gumbel Distributions in the Upper Thames River Watershed under Global Climate Models. Water Resources Research Report; Department of Civil and Environmental Engineering, The University of Western Ontario: London, ON, Canada, 2011; pp. 1-54.

36. Horváthová, B. Povodeň to nie je len vel'ká voda (Flood Is Not Only High Water); Veda: Bratislava, Slovakia, 2003; 224p. (In Slovak) 
37. Kiss, A.; Laszlovszky, J. 14th-16th-century Danube floods and long-term water level changes in archaeological and sedimentary evidence in the western and central Carpathian Basin: An overview with documentary comparison. J. Env. Geogr. 2013, 6, 1-11.

38. Melo, M.; Pekárová, P.; Dujsiková, C.; Melová, K. Povodeň na Dunaji v roku 1895 čast' I: V historických dokumentoch. (The flood on the Danube in 1895 part I: In historical documents). Acta Hydrol. Slovaca 2012, 13, 271-279. (In Slovak)

39. Melo, M.; Pekárová, P.; Miklánek, P.; Melová, K.; Dujsíková, C. Use of historical sources in a study of the 1895 floods on the Danube River and its tributaries. Geogr. Pannonica 2014, 18, 108-116.

40. Mikhailov, V.N.; Morozov, V.N.; Cheroy, N.I.; Mikhailova, M.V.; Zavyalova, E.F. Extreme flood on Danube River in 2006. Russ. Meteorol. Hydrol. 2008, 1, 80-89.

41. Pekárová, P.; Halmová, D.; Bačová Mitková, V.; Miklánek, P.; Pekár, J.; Škoda, P. Historic flood marks and flood frequency analysis of the Danube River at Bratislava, Slovakia. J. Hydrol. Hydromech. 2013, 61, 326-333. [CrossRef]

42. Blöschl, G.; Nester, T.; Komma, J.; Parajka, J.; Perdigão, R.A.P. The June 2013 flood in the Upper Danube basin, and comparisons with the 2002, 1954 and 1899 floods. Hydrol. Earth Syst. Sci. 2013, 17, 9533-9573. [CrossRef]

43. Cheng, K.S.; Chiang, J.L.; Hsu, C.W. Simulation of probability distributions commonly used in hydrological frequency analysis. Hydrol. Process 2007, 21, 51-60. [CrossRef]

44. IACWD. Guidelines for Determining Flood Flow Frequency, Bulletin 17-B; Technical Report; Interagency Committee on Water Data, Hydrology Subcommittee: Reston, VA, USA, 1982; 194p.

45. Stedinger, J.R.; Griffis, V.W. Flood Frequency Analysis in the United States: Time to Update. J. Hydrol. Eng. 2008, 13, 199-204. [CrossRef]

46. Hirsch, R.M. Probability plotting position formulas for flood records with historical information. J. Hydrol. 1987, 96, 185-199. [CrossRef]

47. Hirsch, R.M.; Stedinger, J.R. Plotting position for historical floods and their precision. WRR 1987, $23,715-727$.

48. Hammett, K.M.; DelCharco, M.J. Estimating the Magnitude and Frequency of Floods for Streams in West-Central Florida; U.S. Geological Survey Scientific Investigations Report 2005-5080; U.S. Geological Survey: Reston, VA, USA, 2001; 15p, plus apps.

49. England, J.F., Jr.; Cohn, T.A.; Faber, B.A.; Stedinger, J.R.; Thomas, W.O., Jr.; Veilleux, A.G.; Kiang, J.E.; Mason, R.R., Jr. Guidelines for Determining Flood Flow Frequency_Bulletin 17C; Techniques and Methods: Book 4, Chapter B5; U.S. Geological Survey: Reston, VA, USA, 2018; 148p. [CrossRef]

50. McCuen, R.H.; Smith, E. Origin of floods skew. J. Hydrol. Eng. 2008, 13. [CrossRef]

51. Bondar, C.; Panin, N. The Danube Delta Hydrologic Database and Modelling. GeoEcoMarina 2001, 5, 5-53.

52. Bačová Mitková, V.; Pekárová, P.; Miklánek, P.; Pekár, J. Hydrological simulation of flood transformations in the upper Danube River: Case study of large flood events. J. Hydrol. Hydromech. 2016, 64, 337-348. [CrossRef]

53. Stănescu, V.A.; Ungureanu, V.; Domokos, M. Regionalization of the Danube catchment for the estimation of the distribution functions of annual peak discharges. J. Hydrol. Hydromech. 2001, 49, 407-427.

54. Engeland, K.; Wilson, D.; Borsányi, P.; Roald, L.; Holmqvist, E. Use of historical data in flood frequency analysis: A case study for four catchments in Norway. Hydrol. Res. 2018, 49, 466-486. [CrossRef] 